\title{
The Evolution of The Forest Cover with The Effect of Anthropic Pressure (The Case Study of Sehoul Cork-Oak Forest in Morocco, North Atlantic)
}

\author{
Assmaa ALAOUI ${ }^{1}$, Said LAARIBYA ${ }^{2}$, Sezgin AYAN ${ }^{3 *}$ \\ ${ }^{1}$ Ibn Zohr University, Biology Department, Agadir, MOROCCO \\ ${ }^{2}$ Chouaib Doukkali University, Geography Department, LREDD-El Jadida, MOROCCO \\ ${ }^{3}$ Kastamonu University, Faculty of Forestry, Department of Forest Engineering, Kastamonu, TURKEY \\ *Corresponding Author: sezginayan@gmail.com
}

Received Date: 10.12.2019

Accepted Date: 19.02 .2020

\begin{abstract}
Aim of study: The objectives of this study consist in an examination of the evolution of cork-oak forest in Sehoul forest, Morocco, over two decades and to analyze the impact of the anthropic pressure.

Area of study: The research has been carried on Sehoul forest, located in northwestern Morocco. It is linked to the largest plain cork-oak forest in the world.

Material and method: This work carried via mapping of forest area, socio-economic surveys and participatory workshops, to assess the state of degradation of forest areas and their evolution, and to search for the causes of these with a relationship with human activities.

Main results: Sehoul cork-oak forest is among the forest ecosystems that play a fundamental economic, social and environmental role. However, the current state of its stands is disturbing. The progressive degradation is the result of a combination of climatic and anthropogenic factors that continue to intensify. The degradation of the forest can be expressed by its replacement by introduced species and the reduction of its coverage rate, and the absence of its natural regeneration.

Highlights: The cork-oak forest in Sehoul, firewood-borne forest regression is twice as high as forest production and overgrazing rate is around $80 \%$.
\end{abstract}

Key words: Anthropogenic Pressure, Degradation, Stand Dynamic, Morocco, Quercus suber

\section{Antropik Baskı Etkisiyle Orman Örtüsünün Değişimi (Sehoul Mantar Meşesi Ormanı Vaka Örneği, Fas, Kuzey Atlantik)}

Öz

Çalışmanın amacı: Bu çalışmanın amacı, Fas'da bulunan Sehoul mantar meşesi ormanının 20 yılı aşkın süredeki evriminin incelenmesi ve antropik baskının etkisini analiz etmektir.

Çalışma alanı: Araştırma, kuzeybatı Fas'ta bulunan Sehoul ormanında yürütülmüştür. Sehoul mantar meşesi orman, dünyadaki en geniş ve düz yayılış alanına sahip mantar meșesi ormanı ile bağlantılıdır.

Materyal ve yöntem: $\mathrm{Bu}$ çalışma, orman alanlarının bozulma durumunu ve evrimini değerlendirmek ve bunların nedenlerini insan faaliyetleri ile olan ilişkilerini araştırmak için orman alanı haritalaması, sosyo-ekonomik araştırmalar ve katılımcı atölye çalışmalarıyla yürütülmüştür.

Temel sonuçlar: Sehoul mantar meşesi ormanı, temel ekonomik, sosyal ve çevresel rol oynayan orman ekosistemleri arasındadır. Bununla birlikte, meșcerelerin mevcut durumu iyi nitelikte değildir. İlerleyen degredasyon, sürekli yoğunluğu artan iklim ve antropojenik faktörlerin kombinasyonunun bir sonucudur. Ormanın degredasyonu yeni türlerin introdüksiyonu, örtme derecesinin azalması ve doğal gençleşmenin olmayışı ile ifade edilebilir. Kullanılan yöntem, yöneticileri ve araştırmacıları yönlendirmede etkili bir bilimsel yaklaşım olarak izlenebilir.

Araşttrma vurguları: Sehoul'deki mantar meşesi ormanında, yakacak odun kaynaklı orman azalması orman üretiminden iki kat daha yüksek ve aşırı otlatma oranı $\% 80$ civarındadır.

Anahtar kelimeler: Antropojenik Baskı, Degradasyon, Meşcere Dinamiği, Fas, Mantar Meşesi

\section{Introduction}

In Morocco, the North Atlantic suberia is among the Moroccan forest ecosystems that play a fundamental economic, social and environmental role. Cork-oak species (Quercus suber L.) is endemic to the 
countries of the Mediterranean basin and is classified among the noble essences of the country. It is given special attention because of the diversity of its products and services. However, the current state of cork oak stands is disturbing; They consist largely of old subjects who have undergone a series of constraints reducing their longevity. Their progressive degradation is the result of a combination of biotic and abiotic factors that continue to intensify.

This degradation, which began at the beginning of the $20^{\text {th }}$ century, is mainly due to strong anthropic pressure associated with persistent natural phenomena (aridity of the climate, poor soil and scarcity of water) and inadequate guidelines for management thus face to severe degradation (Laaribya, 2011). In addition, population growth, the accelerated settlement of populations in the enclaves and on the edge of the forest, and the transformation of the modes of exploitation of the spaces of pastoral societies to sedentary human groups have accelerated the phenomenon of degradation through clearing of land, fire, grazing and cutting of trees. This abusive exploitation combined with unsuitable farming provoked the spatial regression of hickories and profoundly altered the balance between vegetation, soil and climate (Laaribya, 2006).

The degradation of these forest ecosystems are manifested through several indicators such as the decline in the area covered by cork oak and their replacement by other introduced species, degradation of rangelands, and soil depletion. The attempts of the State to reconstitute these spaces are often doomed to failure and the strict defenses absolutely conditioning the success of the work of rejuvenation of the forest are difficult to accept by the population. Faced with this situation, it is therefore necessary to promote a new approach based on awareness and the search for appropriate solutions for the conservation and development of these natural resources.

The objectives of this work consist in an examination of the evolution of forest cover over a period of 20 years and an analysis of the impact of antropic pressure on the forest of Sehoul, belonging to North-Atlantic Morocco. The primary results obtained were used to get to know the state of degradation of the forest areas, to look for the causes of this degradation having a relation with the human activities, through an analysis of the spatial distribution of the production systems and an analysis socioeconomic.

\section{Material and Methods \\ Material}

To carry out this study, we targeted the town of Sehoul located in north-west Morocco, between the cities of Rabat and Kenitra (Figure 1). The forest in this town belongs to the largest cork-oak region of the north of the Moroccan Atlantic and is linked to the Maamora forest, which originally occupied an area of more than 130000 ha and was considered to be the largest world cork oak forest. The cork oak forest of Sehoul has an area of 13075,7 ha and is located south of canton A of Maamora in a subhumid bioclimate.

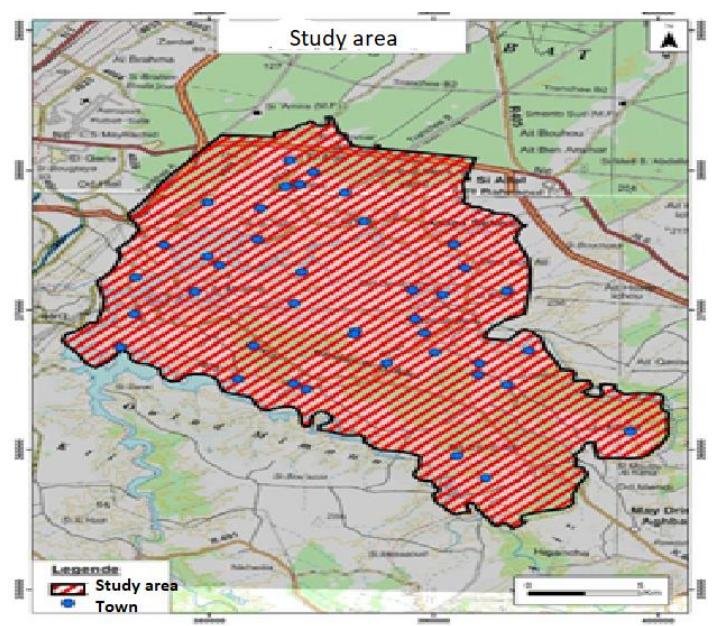

Figure 1. Geographical location of the study area

\section{Methods}

Study and Collection of Basic SocioEconomic Data

At first, we did preliminary field tours to get closer to the local reality. Subsequently, a sample of 8 villages (ie a sampling rate of $29 \%$ of the user villages) is targeted taking into account: (i) the socio-economic problem of the village, (ii) the size of the village, (iii) distance from the forest (iv) local production systems. Then a sample of 140 farms (households), at the level of the villages concerned, was the target of a thorough 
survey. The sounding technique used is based on sampling with 2 stratification criteria, namely the utilized agricultural area (UAA) and the number of small livestock units (UPBs).

The aspects addressed in this survey are structured around a questionnaire made up of several compartments (socio-economic factors, occupation and organization of the space, livestock and rangelands, wood samples taken from the forest, other forestry practices, breeders' suggestions etc.). Also, participatory and concerted workshops with all stakeholders took place; The various actors directly or indirectly related to this issue took part (rural population, elected municipal officials, local authority, regional leaders, foresters, non-governmental organization, etc.) The main problems related to the degradation of the forest are thus synthesized.

For the surveys conducted, we used the Accelerated Participatory Research Method (APRM) and the SWOT method. And for Data Analysis it was used Principal Component Analysis (PCA) through the use of XLSTAT 2010 software, on socioeconomic variables and modeling using linear regression.

\section{Mapping and Analysis of Space Dynamics}

We used the Geographic Information System software (ARCGIS 10.1) to develop: a/ a recovery map of the municipality studied;

b/ a map of the evolution of forest cover for the period from 1986 to 2007, ie 21 years, from the comparison of the state of the most recent forest cover and its reference state in 1986 ;

c/ a forest degradation map and;

d/ a diachronic analysis of the vegetation by exploiting the figures on the general trend of the forest during the last twenty years.

Cartographic work is followed by field verification to validate map results.

\section{Measuring the Impact of Herds on the Pastoral Resources}

- The apparent load is defined by the UPB report on the area of forest rangelands;
- The actual load $(\mathrm{Cr})$ corresponds to the load imposed on the course and is equal to the ratio between the number of UPBs and the area of the forest tracks, taking into account the average number of days spent in the forest which is of the order 220 days according to the declarations of the breeders and the estimation which emanate from the counting of the survey cards.

- The equilibrium load (Ce) is based on the potential of forage production compared to the need for livestock in UPB and the length of stay in the forest.

This = OFFER (UF) / REQUEST (UF)

OFFER: Average forage production estimated at the level of the forest path.

DEMAND: The annual demand for forage unit / UPB (300 UF/ha/yr)

This value is used to calculate the overgrazing coefficient which is: $S=100 *(1-$ $\mathrm{Ce} / \mathrm{Cr}$ ).

\section{Results and Discussion}

\section{Socio-Economic Characteristics}

The population of the municipality of Sehoul is estimated at 19706 . The average household size is about six people. It is a young population, made up of both women and men, with the most active age group (15 to 60 years old) being $58 \%$.

The average illiteracy rate for these two rural communes is very high, exceeding $55 \%$. Depending on the gender, the situation remains worrying if not dramatic for women (Alaoui et al., 2013) with a rate that exceeds $65 \%$. The poverty rate $(22,86 \%)$ is higher than that of the country (15\%), and a vulnerability rate higher than $25 \%$. Women are generally more at risk from this phenomenon than men because they are less likely to be gainfully employed, they generally receive smaller pensions and are more likely to take over the free responsibilities of their households.

\section{Analysis of Production Systems}

The studied area is agro-sylvopastoral vocation; Agriculture in the region has several constraints. The fragmentation of land and the insufficient financial and material means present a real obstacle to the modernization of agricultural practices. Agricultural production is dominated by 
cereals $(70,5 \%)$ followed by fruit plantations $(5,3 \%)$ (Table 1). Yields are still low compared to the potential of the area and vary according to production techniques, the use or not of fertilizers and selected seeds and the nature of the land (Bour or irrigated).

Table 1. Main agricultural crops (Anonymous, 1996)

\begin{tabular}{lrr}
\hline Speculation & Area & $\%$ \\
\hline Cereals & 15511 & 70,5 \\
\hline Legumes & 587 & 2,7 \\
\hline Market gardening & 995 & 4,5 \\
\hline Industrial crops & 160 & 0,7 \\
\hline Forage crops & 860 & 3,9 \\
\hline Fruit Plantations & 1156 & 5,3 \\
\hline Fallow & 2731 & 12,4 \\
\hline Total & 22000 & 100 \\
\hline
\end{tabular}

Livestock is historically the main wealth of the population of the area. It is practiced in semi-extensive to extensive relying mainly on forest rangelands for an average duration of 9 months/year, followed by cultivation lands that provide direct (barley) and indirect (although sometimes low (fallow, stubble), and finally the compound feeds that depend on the financial possibilities of each breeder (Laaribya et al., 2013a).

In order to approach the impact of this breeding on the forest resources, we calculated the balance of fodder, taking into account the herd that moves in the forest. The numbers that regularly graze in the forest according to the forage calendar are $55 \%$ of the UPBs. The rest do not move in the forest for reasons of production methods, constraints of guarding the herd (shepherd), the small size or the remoteness of some villages in the forest. Indirectly measuring the impact of herds on the pastoral resources of the forest uses parameters indicating the level of use of forest rangelands in the study area (Table 2).

The analysis of the indicators developed shows that the fodder potential of forest areas covers only $11,52 \%$ of the annual needs of grazing livestock in the forest. The needs are much higher than the fodder supply of the forest. The pressure exerted on them causes a degradation of forest areas. This degradation is reflected in a very high overgrazing coefficient $(81 \%)$.

Furthermore, given the quality of the fodder provided by the cork oak tree, the shepherds drive their herds much more towards the hollies than to the other artificial species, which causes an unequivocal pressure on the cork oak trees in question where the presence of the cattle in a large number on a full-time basis, prevents any possibility of natural regeneration, by soil compaction and consumption of acorns. As a result, the vegetation cover is deteriorating in a growing and worrying way.

Table 2. Forage balance Main indicators of the forage balance

\begin{tabular}{lr}
\hline Total UPB & 108600 \\
\hline Rate that moves in the forest & $55 \%$ \\
\hline Total UPB in forest & 59730 \\
\hline Feeding needs & 17919000 \\
\hline Forest area (ha) & 8943 \\
\hline Forest potential in UF & 1341375 \\
\hline Forage deficit & $88,48 \%$ \\
\hline Need coverage rate & $11,52 \%$ \\
\hline Apparent load: Ca (UPB/ha) & 6,68 \\
\hline Length of stay (days) & 220 \\
\hline$\%$ Annual & 0,6 \\
\hline Actual load: Cr (UPB/ha) & 4,03 \\
\hline Offer: Average production/ha & 230,79 \\
\hline Request: need a UPB & 300 \\
\hline Actual load & 0,77 \\
\hline Overgrazing coefficient & $81 \%$ \\
\hline
\end{tabular}

Forests are of great importance in the local economy. In addition to the revenues generated for the benefit of the communes, they offer wide rangelands, considerable wealth (acorns, WFP, mushrooms, etc.) and a large amount of firewood used by the user populations to meet their needs in terms of cooking and heating material. The total consumption for all users (3304 households) in the commune of Sehoul is estimated at 26 630 steres/year (with 1 sterre is equal to about $400 \mathrm{~kg}$ of dry firewood). The total output of the Sehoul forest area in fuelwood is estimated at $13075.7 \mathrm{~m}^{3} /$ year. This production is evaluated on the basis of the annual growth of stands, which is about 5 
$\mathrm{m}^{3} /$ ha/year, of which $20 \%$ is firewood, ie 1 sterre/ha/year (Belghazi et al., 2001). Riparian populations are closely dependent on them in their daily lives, but the needs are greater than the possibilities of the forest since fuelwood is twice as much as forest production (Table 3 ).

Table 3. Wood fuel (WF) consumption report

\begin{tabular}{lr}
\hline \multicolumn{1}{c}{ Town } & Sehoul \\
\hline Forest area (ha) & 13075,7 \\
\hline $\begin{array}{l}\text { Forest production in WF/ } \\
\text { year (stère) }\end{array}$ & 13075,7 \\
\hline $\begin{array}{l}\text { Consumption in WF/ } \\
\text { household/year (stère) }\end{array}$ & 8,4 \\
\hline Number of households & 3304 \\
\hline $\begin{array}{l}\text { Consumption/commune in } \\
\text { WF/year (stère) }\end{array}$ & 27737 \\
\hline Deficiency in WF (stère) & 14661,3 \\
\hline Consumption rate $(\%)$ & 212 \\
\hline
\end{tabular}

Apart from the right of use enjoyed by the user population of the forest, delinquency is practiced by most households. They are intended either for sale or to meet the needs of local populations in different forest products (Laaribya et al., 2013b). Forest clearings and encroachments are linked to clear cutting of live wood, charring, construction and encampment and overgrazing in the forest. As a result, the existing capital on the ground begins to a large extent.

An analysis of the data available in the archives of local forest managers is another way of locating the level of pressure exerted on this forest and knowing the sources of its degradation, through the estimation of the different types of crime. Thus, during the period (2005-2012), a total of 428 offenses were recorded, of which: 188 (or 43,92\%) misdemeanors; 194 (or 45,33\%) the offense of cutting live wood, kidnapping and mutilation; 34 (or 7,94\%) carbonization offenses and; 12 (or 2,8\%) various offenses (Figure 2).

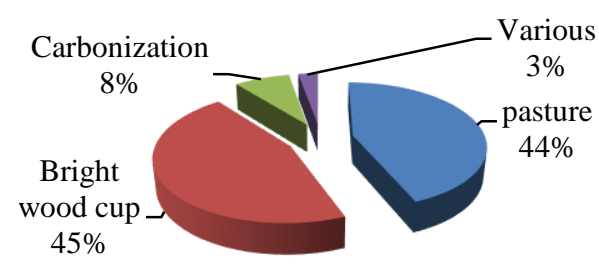

Figure 2. Distribution of offenses

These levies, practiced by some people, are forged around which illicit channels and affect the capital of production and regeneration. Our investigations in the field have shown us that the development of tortious practice is due mainly to the search for a complementary income, the satisfaction of domestic needs and the availability of time for unemployed young people (Alaoui et al., 2012). Despite the administration's efforts to reforest the introduced species and rebuild the cork oaks, the regressive tendency of the forest cover prompts us to put several question marks on the fate of the natural forest areas in this area.

\section{Analysis of Forest Evolution Land Cover and Forest Formations:}

From the map analysis (Figure 4 and 5), the total area of the commune Sehoul is 40256,66 ha. The forest occupies 13075,74 ha or $53,44 \%$ of the area distributed as follows:

- The cork oak (Figure 3) is the main natural forest species represented by 7439,5 ha, ie $57 \%$ of the wooded area (Figure 4 and 5). Thuya (Tetraclinis articulata Vahl. Masters) is the second natural species with 1312,5 ha or $10 \%$ of the forest area followed by other natural hardwoods based on Acacia cyanophylla Lindl. and Tamarix africana Poir. with an area of 796 ha or $6 \%$.

- Hardwood plantations occupy 1465,7 ha, or $11,2 \%$ of the forest area, while softwood reforestation is of less interest with 127,3 ha or $1 \%$ of the forest area; The latter are mainly based on maritime pines.

-A large forest area of 1934,7 ha, or 14,8\%, is occupied by a matorral based on species indicating the disappearance of cork oak (cists, lavender, etc.). 


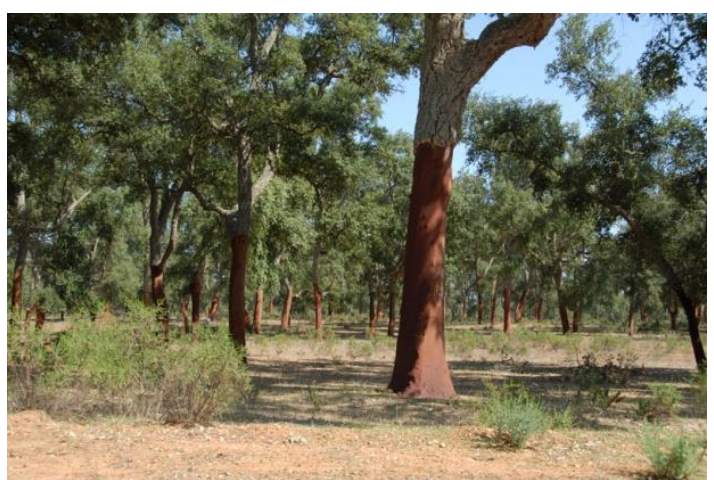

Figure 3. Cork-oak forest

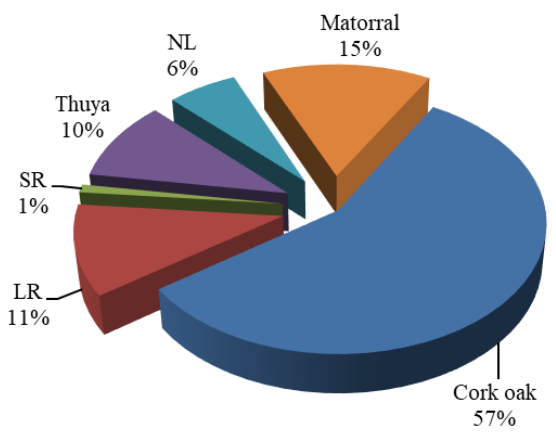

Figure 4: Main forest formations

NL: Natural leafy, SR: Softwood reforestation, LR: Leafy reforestation, Thuya (Tetraclinis articulata)

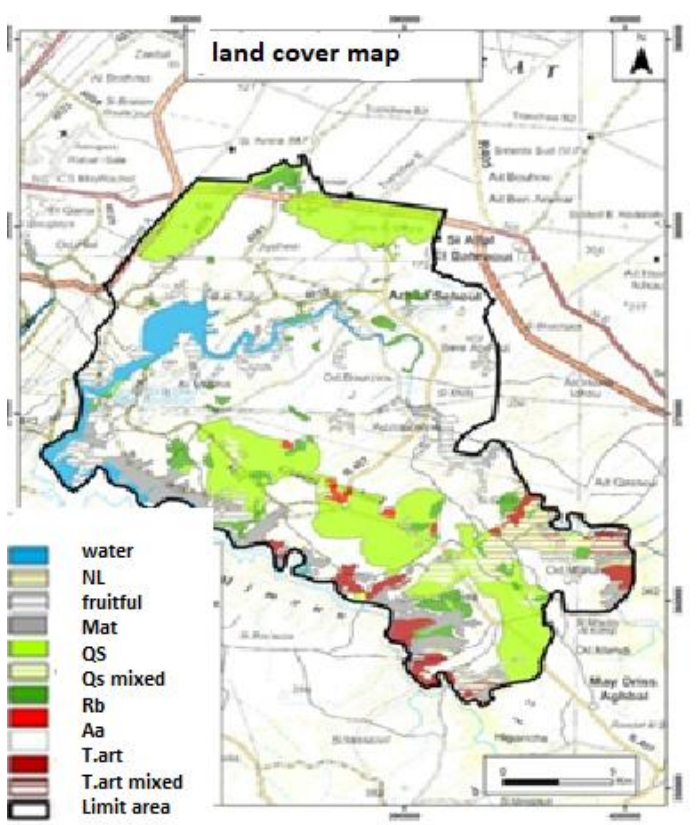

Figure 5. Land cover map

(NL: Natural leafy, Rb: Reforestation, Mat: Matorral, T.art: Tetraclinis, Aa: Agriculture area. QS: Quercus suber)

\section{Evolution of the Forest Area}

The map of forest evolution allows us to shed light on the changes that have affected vegetation cover for 21 years. In addition to the change in surface area experienced by each component of space during this period, the study area experienced a dynamic in its vegetation cover. Some non-forested land became forested and some parts of the forest became non-forested (Figure 6).

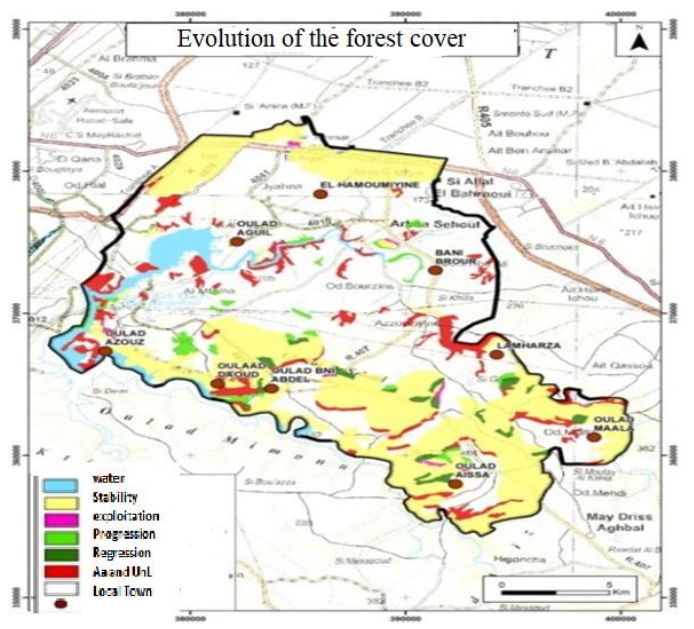

Figure 6. Evolution of the forest cover of the study area

Over the period 1986-2007, the spatial evolution of each unit allowed us to know the rate of regression and progression of the different surface units as shown in the table 4.

Table 4. Main developments recorded in Sehoul

\begin{tabular}{llrr}
\hline \multirow{3}{*}{ Forest (ha) } & Stability & 10504,9 & $90 \%$ \\
\cline { 2 - 4 } & Regression & 1216,1 & $10 \%$ \\
\hline & Progression & 2595,5 & $22 \%$ \\
\hline $\begin{array}{l}\text { Unwooded } \\
\text { land (ha) }\end{array}$ & Stability & 24348,2 & $90 \%$ \\
\hline
\end{tabular}

$90 \%$ of the forest remained stable, compared to an increase of $22 \%$ and a regression of $10 \%$, mainly due to the exploitation of reforestation for the installation of some infrastructures (roads, temporary occupations, etc.) and to the transformation of some parts into water zones (dam) (Alaoui et al., 2011). Indeed, the municipality of Sehoul has undergone a change in its forest cover totaling 3811,7 ha 
or $32,52 \%$ of the forest, divided between 2595,6 ha in progressive evolution against 1216,1 ha in regressive evolution, or a net balance sheet of 1379,4 ha of progressive evolution. This situation is explained by the reforestation efforts undertaken.
The spatial confusion matrix between the cartographic themes of the two aerial photography dates shows that the main component species of the forest areas experienced a certain dynamic during the studied period (21 years) (Table 5).

Table 5. General evolution of the forest canopy (ha)

\begin{tabular}{|c|c|c|c|c|c|c|c|c|c|}
\hline & \multicolumn{8}{|c|}{ Species 1986} \\
\hline & & Water & Mat & Qs & RB & RS & Thuya & UnL & Total \\
\hline \multirow{9}{*}{ 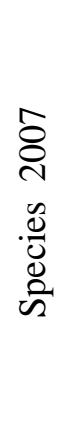 } & Water & 1427,3 & 12,5 & --- & 2,1 & --- & 1,2 & 122 & 1565,2 \\
\hline & NL & 0,8 & 0,4 & 178 & 13,4 & ---- & 565,2 & 38,4 & 796,1 \\
\hline & Mat & 17,5 & 250 & 82,6 & 100,6 & 28,5 & 460 & 995,4 & 1934,7 \\
\hline & Qs & 0,6 & 33.6 & 6208,5 & 365,8 & 124,3 & 58,9 & 647,8 & 7439,5 \\
\hline & $\mathrm{RB}$ & 6,9 & 1,6 & 332 & 243,4 & 58,8 & 191,6 & 631,4 & 1465,7 \\
\hline & RS & --- & ---- & 58,9 & 4,4 & 23,6 & --- & 40,5 & 127,3 \\
\hline & Thuya & 0,7 & 394,1 & 9,9 & ---- & --- & 716,9 & 190,9 & 1312,5 \\
\hline & UnL & 67,1 & 183,7 & 514,1 & 169,1 & 37,8 & 295,6 & 24348,2 & 23417,9 \\
\hline & Total & 1520,9 & 875,8 & 7383,9 & 898,8 & 273 & 2289,5 & 27014,7 & 40256,6 \\
\hline
\end{tabular}

NL: Natural leafy, RB: Reforestation broadleaved, RS: Reforestation softwood, Mat: Matorral, UnL: Unwooded land, Qs: Quercus suber)

Analysis of this table shows the following figure 7:

- A slight increase in the area occupied by cork-oak by 56 ha $(+1 \%)$ and a reduction in the area occupied by thuya 977 ha is a negative variation rate of $(-43 \%)$;

- Forest formations based on hardwood plantations, for their part, increased by 567 ha, a rate of variation of $(+63 \%)$, particularly for eucalyptus trees. Conversely, softwood reforestation has declined in terms of area of 146 ha $(-53 \%)$;

- Matorral area also increased positively by 1058,9 ha $(+121 \%)$.

Coverage Rate and Degradation of Forest Stands

The rate of cover of forest stands is variable depending on the species and the location in relation to the villages. Areas of severe cork oak degradation have an average cover rate of less than $33 \%$. Their surface has $21,5 \%$. Moderately degraded areas have a cover rate between $33 \%$ and $66 \%$ and present
$14 \%$ of the cork oak stand (Table 6). These two categories of degradation zones represent more than $35 \%$. This rate confirms the regressive trend of the forest in this region. If the surface of Matorral is taken into account, the area of degradation will be greater. Laouina et al. (2010) said these oak groves are thus in the centre of interest of several stakeholders with opposite behavior and a new paradigm of relation rural/urban.

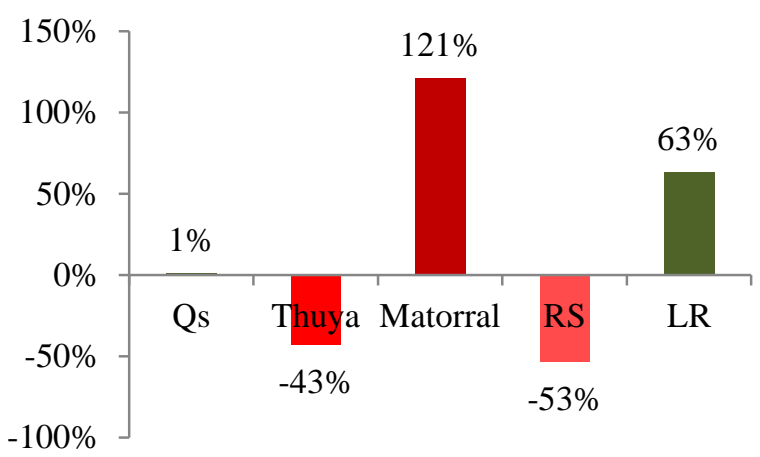

Figure 7. Evolution of the forest cover

Table 6. Forest cover rates in the study area

\begin{tabular}{ccccccccc}
\hline \multirow{2}{*}{ Species } & \multicolumn{2}{c}{$<33 \%$} & \multicolumn{3}{c}{$33 \% \leq \mathrm{d}<66 \%$} & \multicolumn{2}{c}{$\geq 66 \%$} & \multicolumn{2}{c}{ Total } \\
\cline { 2 - 10 } & ha & $\%$ & ha & $\%$ & ha & $\%$ & ha & $\%$ \\
\hline Qs & 1600,6 & 21,5 & 1031,5 & 13,9 & 4807,4 & 64,6 & 7439,5 & 100 \\
\hline
\end{tabular}


(Table 6 continued)

\begin{tabular}{crrrrrrrr}
\hline NL & 25,6 & 3,2 & 207 & 26 & 563,5 & 70,8 & 796,1 & 100 \\
\hline RB & 94 & 6,4 & 123,5 & 8,4 & 1248,3 & 85,2 & 1465,7 & 100 \\
\hline RS & 27,9 & 21,9 & & 0 & 99,4 & 78,1 & 127,3 & 100 \\
\hline Thuya & 490,7 & 37,4 & 569,8 & 43,4 & 252 & 19,2 & 1312,5 & 100 \\
\hline Mat & 1934,7 & 100 & 0 & 0 & 0 & 0 & 1934,7 & 100 \\
\hline
\end{tabular}

The observation of cutlery charts shows a great heterogeneity of the degradation. This degradation is essentially localized near the villages (Figure 8). We can then assume that the human presence plays its role in this phenomenon of regression of the vegetation. This theory is reinforced by the presence of livestock in the forest area near the villages.

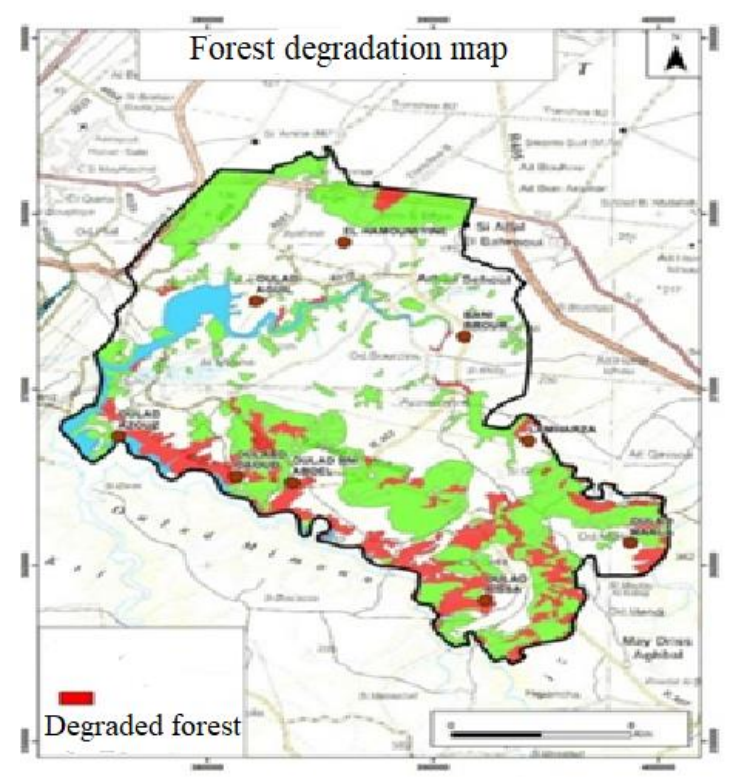

Figure 8. Forest degradation map of Sehoul commune

To these forms of exploitation and degradation of the plant cover, the aged state of the natural stands of cork oak, prevents the possibility of obtaining natural seedlings. As a result, natural regeneration is almost absent. In addition, artificial regeneration efforts are made on fully deforested plots (Alaoui, 2002). These arguments allow us to explain in part, the lack of gain in terms of density of this essence.

\section{Indicators of Degradation of Forest Areas}

The statistical analysis of the cartography as well as the observations of certain facts on the ground enabled us to identify several indicators of degradation namely:

1. The low density of the cork oak: The cartographic verification in the field by the choice of sample plots, related to the whole of the cork oak, allowed us to deduce a very low average current density of 120 trees/ha, which is in below the optimum cork production limit since the desired density in a cork-oak growing is between 250 and 300 stems/ha (AEFCS, 1978).

2. The increase of the matorral space at the expense of the wooded area: space at the expense of the wooded area: The matorral expresses the ultimate stage of degradation of the forest. The results of the mapping show that the matorral space has increased, to the detriment of cork oak and cedar stands and hardwood plantations, a significant area of 1058,9 ha from 875,8 ha in 1986 to 1934,7 ha in 2008.

3. Tree dieback: The decline of the cork oak is apparent throughout the forest area. The results of the 1990 inventory show that 10 to $44 \%$ of the trees are wasted. This phenomenon occurs mainly in the eastern zone known for its unfavorable bioclimatic conditions. Our findings on the ground do not differ much from the results of studies already conducted. Indeed, it has been found that almost $1 / 3$ of the trees are wasted. These diebacks due to the attacks of several xylophages and pests, are favored by the topping and pruning, the operation of gaulage and the harvest of cork carried out by an unskilled labor.

\section{Explanatory Factors of the Degradation Process \\ In order to look for the amplification} factors of fuelwood exploitation (an important factor of degradation), we carried out a principal components analysis, on the following socio-economic variables: the income of women (RF) (since women do not 
own property, are most affected by poverty and therefore fall back on forest resources to meet their daily needs), distance from the forest (Dfor), income of men (HR) income is related to UAA and livestock production), UAA and number of UPB. The detailed results of the analysis of the variables studied are given in table 7 .

Table 7. Socio-economic variables studied

\begin{tabular}{ccccccc}
\hline Variable & Unit & Observations & Min. & Max & Average & $\begin{array}{c}\text { Standard } \\
\text { Deviation }\end{array}$ \\
\hline FW & KG/week & 140 & 10 & 80 & 45,007 & 23,283 \\
\hline WI & DH/month & 140 & 150 & 3600 & 525,714 & 445,501 \\
\hline FD & KM & 140 & 0 & 12 & 3,721 & 3,365 \\
\hline AA & ha & 140 & 0 & 15 & 3,050 & 2,861 \\
\hline SBU & $\begin{array}{c}\text { Number/ } \\
\text { household }\end{array}$ & 140 & 6 & 84 & 29,221 & 18,671 \\
\hline MI & DH/mois & 140 & 0 & 7600 & 2818,243 & 1888,213 \\
\hline
\end{tabular}

FW: Firewood, WI: Woman income, FD: Forest distance, AA: Agricultural area, SBU: Small Betail Unit, MI: Men income, Min: Minimum, Max: Maximum

Data processing first allows us to define the linear correlation coefficients between the variables, then the correlation matrix that groups together the linear correlation coefficients between the two-to-two variables. This summarizes the structure of the linear dependencies between the variables (Table 8 ).

Table 8. Correlation matrix between variables

\begin{tabular}{ccccccc}
\hline Variables & FW & WI & FD & AA & SBU & MI \\
\hline FW & 1 & & & & & \\
\hline WI & $-0,428$ & 1 & & & & \\
\hline FD & $-0,780$ & 0,107 & 1 & & & \\
\hline AA & $-0,536$ & 0,544 & 0,301 & 1 & & \\
\hline SBU & $-0,539$ & 0,587 & 0,222 & 0,950 & 1 & \\
\hline MI & $-0,551$ & 0,425 & 0,255 & 0,932 & 0,958 & 1 \\
\hline
\end{tabular}

To determine the linear combination of the variables, and the correlations between them and the projection axes (factors), we limited ourselves to the axis F1 and F2 because they account for $85 \%$ of the information

(Table

9).

Table 9. Eigenvalues of the correlation axes between the variables and the main axes

\begin{tabular}{lcccccc}
\hline & F1 & F2 & F3 & F4 & F5 & F6 \\
\hline Eigen value & 3,836 & 1,268 & 0,670 & 0,160 & 0,043 & 0,022 \\
\hline Variability (\%) & 63,931 & 21,139 & 11,170 & 2,670 & 0,723 & 0,367 \\
\hline \% Cumulated & 63.931 & 85.070 & 96.240 & 98.910 & 99.633 & 100 \\
\hline
\end{tabular}

The projection of the variables in the space of axes F1 and F2 (Figure 9) shows that:

- The variables: distance between households and forest, income of women, UAA, number of UPBs and income of men are positively correlated with factor1 (F1).
- The distance between households and forest is positively correlated with factor2 (F2) while the other three variables are negatively correlated with factor2 (F2).

- The amount of firewood collected is negatively correlated with both factors (F1) and (F2). 
- This means that the smaller the distance between the household and the forest, the greater the amount of fuelwood collected, and the higher the UAA, the number of UPBs and the income of women and men, the more firewood consumed decreases.

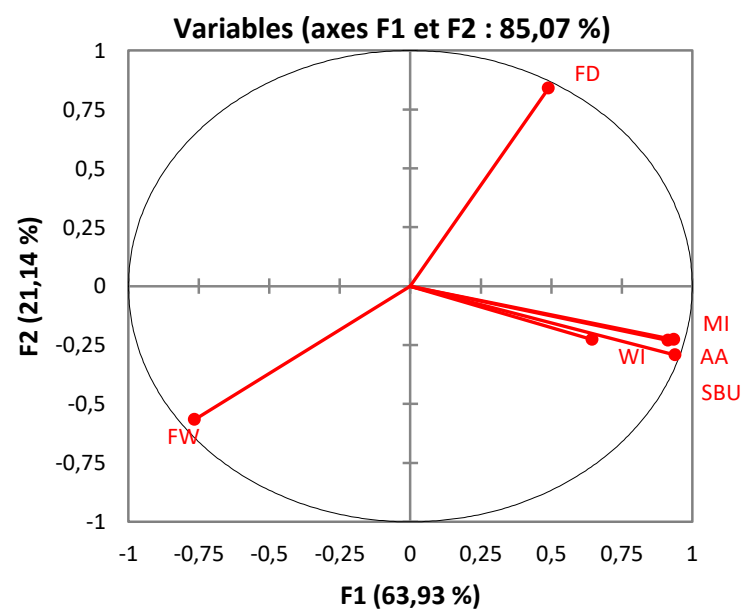

Figure 9. Projection of variables in the space of axes F1 and F2

The Principal Component Analysis also allowed us to identify the population structure and possibly determine the number of groups to build (Figure 10). We can divide the population into three groups, namely:

- A group highly dependent on forest resources; It is especially trained by the poor, living in or near the forest.

- A group dependent on forest resources. Agriculture and livestock are its main sectors of activity.

- An independent group with forest resources because it is far from the forest.

Table 10. Analysis of variance

\begin{tabular}{cccccc}
\hline Source & DDL & $\begin{array}{c}\text { Sum of } \\
\text { squares }\end{array}$ & $\begin{array}{c}\text { Average } \\
\text { squares }\end{array}$ & F & Pr $>$ F \\
\hline Model & 4 & 457754596 & 114438649 & 408,397 & $<0.0001$ \\
\hline Error & 135 & 37828916,1 & 280214,193 & & \\
\hline Total corrected & 139 & 495583512 & & & \\
\hline
\end{tabular}

DDL: Degree of freedom

The variance analysis table and the associated Fisher F test actually indicate that the model is globally very significant with
- It can therefore be concluded that the degree of forest degradation depends inter alia on the economic situation of households and the distance to the forest.

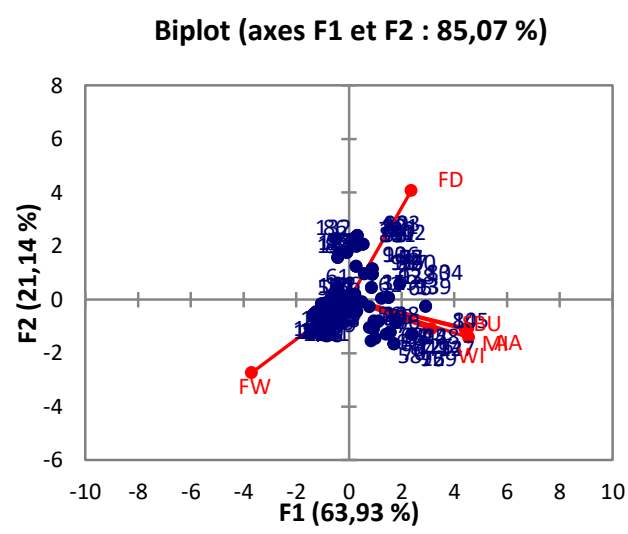

Figure 10. Distribution of observations in the $\mathrm{F} 1$ and $\mathrm{F} 2$ axis space

\section{Modeling Degradation Factors: Linear Regression}

Regression models are equations that translate the relationships between a dependent variable and one or more independent variables. In order to propose a quantitative data model, we used multiple linear regression. This is a statistical analysis that describes, in the form of a model, the variations of an endogenous (dependent) variable associated with the variations of the so-called exogenous (independent) study variables. In our case, the dependent variable is income, the independent variables are the other indicators studied (Table 10) (FW: Quantity of firewood, FD: Forest distance, AA: Agricultural area, SBU: Small betail unit.
$\mathrm{F}=408,397$. The probability associated with $\mathrm{F}$ is in our case less than 0.0001 . This means that we take a risk of being less than $0.01 \%$ 
by concluding that the explanatory variables bring a significant amount of information to the model.

Table 11 provides details on the model. These details are essential to know whether the model should be used for forecasts, simulations, or whether it should be compared to other results.

Table 11. Model parameters

\begin{tabular}{ccccccc}
\hline Source & Value & $\begin{array}{c}\text { Standard } \\
\text { error }\end{array}$ & $\mathrm{t}$ & $\operatorname{Pr}>|\mathrm{t}|$ & $\begin{array}{c}\text { Lower } \\
\text { bound } \\
(95 \%)\end{array}$ & $\begin{array}{c}\text { Upper } \\
\text { bound } \\
(95 \%)\end{array}$ \\
\hline Constant & 484,295 & 347,994 & 1,392 & 0,166 & $-203,93$ & 1172,52 \\
\hline FW & $-4,469$ & 3,999 & $-1,118$ & 0,266 & $-12,377$ & 3,439 \\
\hline FD & $-8,599$ & 24,922 & $-0,345$ & 0,731 & $-57,886$ & 40,689 \\
\hline AA & $154,085^{* *}$ & 54,392 & 2,833 & 0,005 & 46,514 & 261,655 \\
\hline SBU & $71,767^{* * *}$ & 8,803 & 8,153 & $<0,0001$ & 54,358 & 89,177 \\
\hline
\end{tabular}

FW: Firewood, WI: Woman income, FD: Forest distance, AA: Agricultural area, SBU: Small Betail Unit, MI: Men, ** Significant at the $5 \%$ level, *** Significant at the $1 \%$ level

The chosen model:

$$
\begin{gathered}
\mathbf{M I}=484,29-4,47 * \mathbf{F W}-8,59 * \mathbf{F D}+ \\
154,08 * \mathbf{A A}+71,77 * \mathbf{S B U}+\mathbf{e} \\
\mathrm{R}^{2}=0,92 \quad \mathrm{R}^{2} \text { adjusted }=0,92 \quad \mathrm{DW}=1,646
\end{gathered}
$$

From the results obtained, we can confirm the results of the analysis in main component. Indeed, the amount of fuelwood, the distance to the forest is negatively correlated with income, while the UAA and the UPB are positively correlated. However, the analysis of the probabilities associated with the student $t$ test shows that only the UAA and the UPB are significant at the threshold of $5 \%$ and $1 \%$, respectively. These are therefore the most important variables in the formation of household incomes. In fact, having more useful agricultural land combined with the use of seeds allows farmers to move towards intensive agriculture and value-added. As a result, farmers improve the income generated by agriculture.

The results also confirm that livestock is an essential component in the agricultural economy of the area. However, the pressure exerted on the resources of the forest forces the local actors to reconsider the mode of breeding as well as the mechanisms of its management (limitation of the pastoral charge, pastoral inscriptions, animal health, etc.).

\section{Conclusion}

The analysis of production systems indicates that the local population is mainly engaged in agro-sylvopastoral activities. Agricultural production is dominated by cereals and yields are still low compared to the potential of the area.

Regarding livestock, although extensive, remains the capital sector of the economy of the area, both in terms of the use of space, as the level of household income. Livestock take their food mainly from the forest estate throughout the year, especially for the landless. Herds have been grazed 9 months out of 12 in the forest.

As for the forest, it is of great importance in the local economy. In addition to the revenues generated for the benefit of the municipality, it offers wide rangelands, considerable wealth and a large amount of firewood used by the user populations to meet its needs for cooking and heating (Laaribya et al., 2011). Indeed, the riverside populations are closely dependent on them in their daily lives, they mainly benefit from the two main forest products (firewood and rangelands). However, the needs are greater than the possibilities of the forest; fuelwood withdrawals are twice as high as forest production and the rate of overgrazing is in the order of $80 \%$. These levies are therefore at the expense of forest capital already seriously threatened. In addition, despite the efforts of the administration in reforestation 
of introduced species and recovery of cork oak, the retrogressive trend of cork oak, expressed by its replacement by introduced species and the reduction of its cover rate, pushes us to put several question marks on the future of this forest, insofar as the natural regeneration problem persists and threatens the future of this national forest heritage.

\section{References}

AEFCS (1978). Plan national de reboisement: Guide pratique du reboiseur au MAROC.

Anonymous (1996). RGA-Ministry of Agriculture, 1996 Recenssement general de l'Agricuture Maroc-data base.

Alaoui A. (2002). Contribution à l'étude de l'écologie, production, croissance et productivité des principales essences de Reboisement au Maroc. Mémoire d'ingénieur d'état de l'ENFI-Maroc.

Alaoui A., Laaribya S. \& Gmira N. (2013). La femme rurale et le développement durable au Maroc- Constats et perspectives d'évolutionUniversité Ibn Zohr Agadir - Publications locales- regards sociologiques.

Alaoui A., Laaribya S. \& Gmira N. (2011). Production, croissance et modèles de conduite sylvicoles des principales essences (le pin maritime et le pin d'Alep) de reboisement au Maroc. Kastamonu University Journal of Forestry Faculty, 11(1), 68-84.

Alaoui A., Laaribya S., Gmira N. \& Benchekroun F. (2012). Involvement of Rural Women in Local Development and Preservation of Natural Resources-Case of The Rural Municipality Sehoul-Morocco, Kastamonu University Journal of Forestry Faculty, 12(2), 261-269.
Belghazi B., Ezzahiri M., Amhajar M. \& Benzyane M. (2001). Régénération artificielle du chêne-liège dans la forêt de la Mâamora (Maroc) Revue de la forêt Méditerranéennet. XXII, $\mathrm{n}^{\circ}$ 3, novembre 2001.

Laaribya S. (2006). Il faut sauver la forêt de la Maâmora (Maroc). Revue de la forêt Méditerranéenne. T. XXVII, n ${ }^{\circ}$, 65-72.

Laaribya S. (2011). Dynamique des espaces forestiers et plan stratégique de gestion et de développement socioéconomique de la forêt de la Maamora- Thèse de Doctorat en sciences de la vie et de l'environnement- Faculté des sciences de Kenitra.

Laaribya S., Alaoui A. \& Gmira N. (2013a). L'évaluation de la pression pastorale dans la Maamora-Parcours forestiers et surpâturageNature \& Technology, University Hassiba Benbouali of Chlef Journal, Algeria.

Laaribya S., Gmira N., Alaoui A. \& Tomei P.E. (2013b). I prodotti forestali non legnosi, un'occasione di sviluppo locale. Il caso della foresta della Maamora (Marocco). RevueINTER NOS-Quaderni della Sezione di Botanica et Geobotanica Applicate - PISA University (Italie).

Laaribya S., Gmira N. \& Alaoui A. (2011). La Maamora au Maroc, Un enjeu essentiel de développement pour les populations locales, revue sylva belgica - pages 32 à 37 Numero Juillet Aout - 118-4/2011. Belgique.

Laouina, A., Aderghal, M., J. Al Karkouri, J., Antari, M., Chaker, M., Laghazi, Y., Machmachi, I., Machouri, N., Nafaa, R., Naïmi, K., Nouira, A. \& Sfa, M. (2010). The efforts for cork oak forest management and their effects on soil conservation, Forest Systems, 19(2), 263-277. 